\title{
Effect of Organic Manure on Growth and Yield of Wheat for using SWI (System of Wheat Intensification) Method-under Drumstick Tree Based Agroforestry System
}

\author{
Surla Govind Raju*, Biswarup Mehra and Kodam swathi \\ Department of Agroforestry, SHUATS, Prayagraj, India \\ *Corresponding author
}

\begin{tabular}{l} 
Key w o r d s \\
Wheat, Growth \\
analysis, Drumstick, \\
FYM, \\
Vermicompost, \\
Poultry Manure, Pig \\
manure \\
\hline Article Info \\
\hline $\begin{array}{l}\text { Accepted: } \\
\text { 20 June } 2021 \\
\text { Available Online: } \\
\text { 10 July 2021 }\end{array}$ \\
\hline
\end{tabular}

\section{A B S T R A C T}

A field experiment was conducted to determine the Effect of Organic manure on growth and yield of Wheat using SWI (System of Wheat Intensification) Method under Drumstick (Moringa oleifera) based Agroforestry System during the rabi season of 2019 the experiment was laid out in a Randomized block design with three replications 9 treatments (viz. control, FYM, Poultry manure, Pig manure and Vermicompost with SWI method and Traditional method of sowing respectively) at forest nursery and research center College of Forestry, SHUATS, Prayagraj. There are using different organic manures on growth and yield \& best treatment combination, economics for wheat cultivation agroforestry system. From the study it is concluded that the out of 9 treatment $T_{4}$ Vermicompost with SWI is highly recommended for wheat cultivation under Drumstick based Agroforestry system It was worth by sowing maximum plant height $\mathrm{T}_{4}(88.27 \mathrm{~cm})$ number of tillers per plant (16.17) dry weight (26.50 gm) length of spike (15.97 $\mathrm{cm}$ ) was observed under treatment vermicompost with Swi which may be more preferable for farmers since it is economically more profitable and also achieved statistical parity with and hence recommended to the farmers.

\section{Introduction}

Agroforestry is a method of land use management in which trees or shrubs are planted around or between crops or pastures. This deliberate combination of agriculture and forestry has many advantages, such as substantially increased staple food crop yields, increased income-generating livelihoods for farmers, increased biodiversity, improved soil structure and health, decreased erosion, and carbon sequestration. Agro forestry activities in the tropics are extremely advantageous,

Moringa oleifera Lam commonly known by various name like drumstick, moringa, sahajan belongs to family Moringaceae. The name of the tree varied in different provinces of the 
country according to its vicinity. With its great medical, industrial, fruit, fodder, and fuel values for both humans and their livestock, Moringa is a wonder tree.

Wheat (Triticum aestivum L.) is one of the key cereal crops with a special protein (gluten) that is eaten by humans and cultivated in various ecosystems around the world. In an area of around 220 million hectares, wheat is grown globally, with a record production of 763.06 million tonnes of grain. Another method of sowing based on the principles of the Rice Intensification System (SRI) is a modern technique of wheat cultivation (System of Wheat Intensification), Which allows the plant to be held at a distance of 20 $\mathrm{cm}$ and $20 \mathrm{~cm}$ between the lines. This form of sowing with adequate plant density allows adequate aeration, moisture, sunlight and nutrient availability to contribute to the proper production of the root system from the early stage of crop growth.

Intensive cultivation involving extensive highyielding varieties has contributed to heavy nutrient removal from the soil over the past three decades. The productivity of a crop is regulated by several variables, which are primarily the mineral nutrition of nitrogen in particular. Therefore, it is important to make judicious use of organic manure and its scientific management in order to maintain the soil and to achieve the production potential of crops. It should be emphasized that the importance of soil improvement of FYM, vermicompost, poultry manure and pig manure is due to their nutrient content, in addition to helping to boost soil structure and water holding ability of soil

Vermicompost is an aerobically degraded organic matter that has been subjected to chemical degradation by the enzymatic action of worm guts and enzymes of the related microbial community.
Poultry manure is a rich source of nutrients that are macro $(\mathrm{N}, \mathrm{P}, \mathrm{K})$ and micro $(\mathrm{S}, \mathrm{Fe})$ and has a stronger impact on soil health as well. It functions as an organic material for the soil, improves the biological life of the soil and improves the holding capacity of soil water. PM mineralization is greater than other natural manures (cattle, pig), because when added to the soil for plant uptake, it readily releases the nutrients

Farmyard manure enhances the physical condition of the soil by increasing the ability to retain water for full water use. By the cation exchange ability and providing various vitamins, hormones and organic acids that are very important for soil aggregation and for beneficial micro-organisms, it also improves the chemical and biological condition of the soil. They are interested in different biochemical processes and nutrient releases. FYM and inorganic $\mathrm{N}$ incorporation, wheat production and monetary returns can be improved by preserving or improving soil fertility.

\section{Materials and Methods}

The field experiment was carried out at College of Forestry Sam Higginbottom University of Agriculture, Technology \& Sciences, Prayagraj U.P. India during Rabi season of 2019-20 The maximum temperature in summer may reach up to $50^{\circ} \mathrm{C}$ and minimum temperature in winter may fall up to $6^{\circ} \mathrm{C}$. The ten year old plantation of Drumstick tree at 9x3 m spacing inter-cropped. The experiment was laid out in Randomized block design with 3 replications and 09 treatments.

The organic manure FYM, poultry manure, pig manure and Vermicompost. Wheat was sown on 10 Nov 2019 at a row spacing of 25 X 30cm (Traditional) 20X $20 \mathrm{~cm}$ (SWI). The source of nitrogen was FYM (Farm Yard Manure) 12t/ha Poultry manure 08t/ha Pig 
manure06t/ha Vermicompost 06t/ha was applied 27 to all the plots uniformly and was incorporated into the soil at the time of land preparation. The treatment comprised of $\mathrm{T}_{0}$ Control (No manure), $\mathrm{T}_{1} \mathrm{FYM}+\mathrm{SWI}$ Method), $T_{2}$ (Poultry manure + SWI Method), $\mathrm{T}_{3}$ (Pig manure + SWI Method), $\mathrm{T}_{4}$ (Vermicompost + SWI Method), $\mathrm{T}_{5}(\mathrm{FYM}+$ Traditional method), $\mathrm{T}_{6}$ (Poultry manure + Traditional method), $\mathrm{T}_{7}$ (Pig manure + Traditional method), $\mathrm{T}_{8}$ (Vermicompost + Traditional method).

\section{Results and Discussion}

\section{Plant Height (cm) at Harvest}

Data presented in table indicates that the maximum Plant Height $(\mathrm{cm})$ at 120 DAS was observed in treatment T4 $(88.27 \mathrm{~cm})$ and followed by treatment $\mathrm{T} 2(87.20 \mathrm{~cm})$ in wheat.

The minimum Plant Height $(\mathrm{cm})$ was observed in treatment T5 $(82.20 \mathrm{~cm})$ and followed by treatment T0 $(83.20 \mathrm{~cm})$ in wheat under Drumstick based agroforestry system. The result obtained in this research work was found significant at Harvest.

\section{Number of tillers per plant (no) at Harvest}

Data presented in table indicates that the maximum Number of tillers per plant (no) at 120 DAS was observed in treatment T4 (16.17) and followed by treatment T2 (15.50) in wheat variety (PBW-343). The minimum of Number of tillers per plant (no) was observed in treatment T6 (6.40) and followed by treatment T5 (6.43) in wheat variety (PBW343) under Drumstick based agroforestry system. The result obtained in this research work was found significant at Harvest.

\section{Dry Weight (gm) at 120DAS}

Data presented in table indicates that the maximum Dry Weight (gm) at Harvest was observed in treatment T4 $(26.50 \mathrm{gm})$ and followed by treatment $\mathrm{T} 8(26.07 \mathrm{gm})$ in wheat. The minimum Dry Weight (gm) was observed in treatment T6 (18.47 gm) and followed by treatment T5 and T7 (18.60 gm) in wheat variety (PBW-343) under Drumstick based agroforestry system. The result obtained in this research work was found significant at Harvest.

\section{Length of spike (cm) at harvesting time}

Data presented in table indicates that the maximum length of spike at harvesting time was observed in treatment T4 $(15.37 \mathrm{~cm})$ and followed by treatment $\mathrm{T} 2(15.20 \mathrm{~cm})$ on wheat variety (PBW-343). The minimum length of spike was observed in treatment T5 (13.33 $\mathrm{cm})$ and followed by treatment T6 $(13.87 \mathrm{~cm})$ on wheat variety (PBW-343) normal per dry seed sowing under Drumstick based agroforestry system. The result obtained was found significant throughout the study.

\section{Number of grains per spike}

Data presented in table indicates that maximum number of grains per spike at harvesting time was observed in treatment $\mathrm{T} 4$ (52.97) and followed by treatment T2 (50.40) on wheat variety (PBW-343). The minimum number of grains per spike was observed in treatment T6 (43.07) and followed by treatment $\mathrm{T} 7$ (43.57) on wheat variety (PBW343) normal per dry seed sowing under Drumstick based agroforestry system. The result obtained was found significant throughout the study. 
Table.1 Effect of different types of organic manure on growth of Wheat under Drum stick based Agroforestry system at 120 DAS.

\begin{tabular}{|c|c|c|c|c|c|c|}
\hline & $\begin{array}{c}\text { Treatment } \\
\text { Combination }\end{array}$ & $\begin{array}{c}\text { Plant } \\
\text { Height } \\
\text { (cm) }\end{array}$ & $\begin{array}{c}\text { Number of } \\
\text { tillers per } \\
\text { plant }\end{array}$ & $\begin{array}{c}\text { Dry } \\
\text { Weight } \\
\text { (gm) }\end{array}$ & $\begin{array}{c}\text { Length of } \\
\text { spike(cm) }\end{array}$ & $\begin{array}{c}\text { Number of } \\
\text { grains per } \\
\text { spike (cm) }\end{array}$ \\
\hline T0 & Control & 83.20 & 7.47 & 21.80 & 14.97 & 44.37 \\
\hline T1 & F1 X P1 & 85.67 & 14.37 & 22.70 & 14.57 & 49.60 \\
\hline T2 & F2 X P1 & 87.20 & 15.50 & 26.07 & 15.20 & 50.40 \\
\hline T3 & F3 X P1 & 85.83 & 14.53 & 23.43 & 14.97 & 50.37 \\
\hline T4 & F4 X P1 & 88.27 & 16.17 & 26.50 & 15.37 & 52.97 \\
\hline T5 & F1 X P2 & 82.20 & 6.43 & 18.60 & 13.33 & 42.90 \\
\hline T6 & F2 X P2 & 83.73 & 6.40 & 18.47 & 13.87 & 43.07 \\
\hline T7 & F3X P2 & 83.70 & 7.00 & 18.60 & 14.33 & 43.57 \\
\hline T8 & F4 X P2 & 84.43 & 7.27 & 19.17 & 14.50 & 46.30 \\
\hline
\end{tabular}

In view of the findings and results presented above, it is concluded that among all the nine different treatments, $\mathrm{T}_{4} \quad\left(\mathrm{~F}_{1} \mathrm{~T}_{4}\right)$ i.e., Vermicompost with SWI is highly recommended for cultivation under Drumstick based Agroforestry system. It was worth by sowing maximum plant height $\mathrm{T}_{4}(88.27 \mathrm{~cm})$ number of tillers per plant (16.17) dry weight $(26.50 \mathrm{gm})$ length of spike $(15.97 \mathrm{~cm})$ was observed under treatment vermicompost with Swi which may be more preferable for farmers since it is economically more profitable and also achieved statistical parity with and hence recommended to the farmers.

\section{References}

Ajayi, C. A., Williams, O. A., Famuyide, O. O and Adebayo, O. (2013) Economic Potential of Moringa oleifera As A Commercial Tree Species And Its Suitability For Forest Management Intervention In Taungya Farming System. Agrosearch 13 No.3: $242-$ 255

Abraham, B., Araya, H., Berhe, T., Edwards, S., Gujja, B., Khadkas, R. M., Koma, Y S., Sen, D., Sharif, A., Styger, E.,
Uphoff, $\mathrm{N}$ and Verma, A. 2014. The system of crop intensification: reports from the field on improving agricultural production, food security, and resilience to climate change for multiple crops. Agriculture and food security, $3: 4$

Bhargava, C., Deshmukh G., Sawarkar S. D., Alawa S. L. and Ahirwar, J. (2016). The system of wheat intensification in comparison with convention method of wheat line sowing to increase wheat yield with low input cost. Plant Archives 16 (2):801- 804.

Chatterjee, K., Singh, C. S., Singh, A. K., Ashock, K. R. and Singh, S. K. 2016. Performance of wheat cultivars at varying fertility levels under system of wheat intensification and conventional method of wheat production system. Journal of Applied and Natural Science 8 (3): 1427-1433.

Enujeke, E. C. (2013). Effects of poultry manure on growth and yield of improved maize in Asaba area of delta state, Nigeria. J. Agri. Vet. Sci.4: 2430. 


\section{How to cite this article:}

Surla Govind Raju, Biswarup Mehra and Kodam swathi. 2021. Effect of Organic Manure on Growth and Yield of Wheat for using SWI (System of Wheat Intensification) Method-under Drumstick Tree Based Agroforestry System. Int.J.Curr.Microbiol.App.Sci. 10(07): 474-478. doi: https://doi.org/10.20546/ijcmas.2021.1007.052 